\title{
Myths and Misconceptions in Developmental and Neuro-Psychology
}

\author{
Adrian Furnham \\ Norwegian Business School, Oslo, Norway \\ Email: a.furnham@ucl.ac.uk
}

How to cite this paper: Furnham, A. (2018). Myths and Misconceptions in Developmental and Neuro-Psychology. Psychology, 9, 249-259.

https://doi.org/10.4236/psych.2018.92016

Received: January 22, 2018

Accepted: February 20, 2018

Published: February 23, 2018

Copyright $\odot 2018$ by author and Scientific Research Publishing Inc. This work is licensed under the Creative Commons Attribution International License (CC BY 4.0).

http://creativecommons.org/licenses/by/4.0/

\section{c) (i) Open Access}

\begin{abstract}
The current study examined the prevalence of psychological myths and misconceptions in two areas of psychology: Developmental and Neuro-Psychology. In all 220 participants completed two questionnaires both derived from two recently published books, in which they rated to what extent, they thought various statements/facts about the brain and about child development were True or False. A large number of these myths were rated as True (Definitely or Partly) indicating the extent to which people had misconceptions about this area of psychology. There were few significant demographic correlates of the total correct score (determined by rating the myth as False) indicating no clear pattern in what sort of person has these misconceptions. Implications and limitations are discussed.
\end{abstract}

\section{Keywords}

Psychology, Education, Myths, Misconceptions, Psychological Knowledge, Misrepresentations

\section{Introduction}

There is a long-standing academic interest in the belief in psychological myths and misconceptions about the subject (Brown, 1983; Furnham, 1992, 1993; Kowalski \& Taylor, 2009; Nixon, 1925; Lamal, 1979; McKeachie, 1960; Taylor \& Kowalski, 2004; Tupper \& Williams, 1986; Vaughan, 1977). Studies have assessed student's psychological knowledge with a view to evaluating the success of introductory courses, namely the increase in knowledge and reduction of myth acceptance (Arntzen, Lokke, Lokke, \& Eilertsen, 2010; Gardner \& Dalsing, 1986; Griggs \& Ransdell, 1987; Lamal, 1979; McKeachie, 1960; Standing \& Huber, 2003; Vaughan, 1977). Generally, results have been consistent, showing high levels of misconceptions $(40 \%-70 \%)$ prior to education, which are reduced, but 
only slightly, following education methods (LaCaille, 2015). This has surprised and disappointed educationists.

This research area has been galvanized by a very popular book by Lilienfeld, Lynn, Ruscio, and Beyerstein (2010), 50 Great Myths of Popular Psychology. The 50 myths cover diverse areas of psychology, ranging from myths about the brain and perception to myths concerning psychology and the law. They also presented 250 other "mythlets" in need of exploration, which they suggest serving as a useful list of urban legends, misconceptions and non-proven assertions to investigate. Numerous studies have used the 50 myths and 250 mythlets to test various hypotheses in this area (Furnham \& Hughes, 2014; Swami et al., 2015). Other recent books, in a series on psychological myths, have been published looking at specific myths (De Bruyckere, Kirschner, \& Hulshof, 2015).

Further, the Lilienfeld et al. (2010) book has spurred on researchers to develop new scales. Gardner and Brown (2013) developed a new 55-item measure of psychological misconceptions which had good internal consistency. They found overall scores were significantly and negatively correlated with reported reading of news magazines. Bensley, Lilienfeld and Powell (2014) developed a 40-item measure based on the same source and showed that belief in psychological misconceptions was predicted by measures of paranormal belief, faith in intuition, the ability to distinguish scientific fields and practices from pseudoscientific ones, and academic scores.

There has however been little exploration of the personal correlates of those holding myths and misconceptions in psychology. That is, not many studies in this area have looked at demographic (age, education, sex) or psychographic correlates of misconceptions so it is not clear if some groups are more prone to holding myths than others.

The Lilienfeld et al., (2010) book also inspired other various more specialized books with a very similar title and format. This study is based on two of these books. The first was entitled Great Myths of the Brain which listed 41 myths under various headings like defunct myths, immortal myths, myths about the physical structure of the brain (Jarrett, 2014). The second was Great Myths of Child Development and listed 50 myths under various headings such as growth, body, mind; emotions and behavior and social environment. The study followed the methodology of Furnham and Hughes (2014) who asked participants to rate each myth as either Definitely True, Probably True, Probably False, Definitely False or Don't Know. As studies have done with the Lilienfeld et al., (2010) book, we used the same wording as that in the book.

We hypothesized, based on previous results, that for over $50 \%$ of the myths in both categories participants would rate them as Definitely or Probably True. That is, participants would endorse popular myths. We also hypothesized that those with some education in psychology would have a higher correct score, namely recognizing the myth as such. Thus there would be a positive correlation between psychological education and the rejection of other myths. We explored 
other various correlates of misconceptions such as sex, age and ideology but entertained no specific hypotheses about the relationship.

\section{Method}

\subsection{Participants}

A total of 220 participants completed the two questionnaires. $51.8 \%$ were men and $48.2 \%$ were women. They ranged in age from 19 to $66 \mathrm{yrs}$, with the mean age was 35.74 years ( $\mathrm{SD}=10.89$ years). In all $76.4 \%$ identified themselves as White, 9.1\% Black, 6.8\% Asian and 5.9\% Hispanic. In all 27.3\% had secondary school education and $59.1 \%$ were graduates. $46.4 \%$ of the respondents had children. Thirty-four percent (267) had undertaken some previous study of psychology or psychiatry at school, college or university. They are rated themselves on three scales: Compared to other people, how much common sense do you believe you have (Very Little 1 to $8=$ Very Much) and they scored 6.11 (SD = 1.32); How religious are you? (Not all at 1 to Very 8 ) and they scored 3.98 ( SD = 2.06); and How would you describe your political beliefs? (Very Left Wing 1 to Very Right Wing 8); they scored $3.99(\mathrm{SD}=2.08)$.

\subsection{Measures}

The myths and misconceptions were derived from two books, in series, of myths in psychology: Developmental Psychology (Hupp \& Jewell, 2015) and Brain Psychology (Jarrett, 2014). Response options were broken down into "Probably" and "Definitely" True or False allowing for greater information to be gleaned regarding the kinds of True and False responses. In addition, the "Don't Know" option improves upon some previous tests as participants could indicate a lack of knowledge, rather than guessing or leaving items unanswered (Arntzen et al., 2010). This followed the same successful format of Furnham and Hughes (2014).

\subsection{Procedure}

Departmental ethical approval was first obtained. Data was gathered using M-Turk which is a crowdsourcing internet marketplace allowing individuals to complete online tasks in exchange for monetary compensation. MTurk samples have been shown to be more demographically-diverse compared to standard internet samples and the website is considered to be a source of high-quality data for social science research (e.g., Buhrmester, Kwang, \& Gosling, 2011) data collection. The questionnaire took an average of 40 minutes to complete. Data were inspected and cleaned before analysis resulting in the loss of 30 people from the original sample of 250 .

\section{Results}

\subsection{Prevalence of Misconceptions}

All of the items presented were myths, thus for all items, the "correct" answer was False (Probably or Definitely). Participants' False responses were summed in 
order to create a myth recognition score for each of the two questionnaires.

\section{Item level analyses}

Brain Myths: Table 1 shows the results for the 56 Brain myths. In all 15 were identified by more than $50 \%$ of the participants as Definitely False; that is that they were actually recognized as myths. The top five were 5: Drilling a hole in the head releases evil spirits (91\%); 2: The brain pumps animal spirits around the body (81\%); 40: Strokes only affect old people (81\%); 39: A concussion is not a form of brain injury (71\%); and 41: The effects of strokes are limited to physical ability (72\%).

On the other hand there were four items where over $40 \%$ of the respondents said that the following items were Definitely True: 21 : The brain is very well designed (57\%); 35: After head injury, people can forget who they are and not recognize others, but be normal in every other way (51\%); 5: The Brain receives information from the five separate senses $(43 \%)$ and 2: Brain cells join together forming a huge net of nerves (41\%).

On various items a quarter or more of the respondents said that they Don't Know; 24: Glial cells are little more than brain "glue" (54\%); 25: Mirror neurons make us human (52\%); 38: Epilepsy is caused by abnormalities in blood flow in the brain (34\%) and 13: The female brain is more balanced than the male brain (25.9\%).

Developmental Myths: Table 2 shows the results for the 49 Developmental myths. In all 3 were identified by more than $50 \%$ of the participants as Definitely False. They were 8: The Chinese lunar year calendar accurately predicts the sex of a baby (69\%); 3: Parents can predict the sex of a fetus by examining the shape of a mother's body (64\%); and 2: Couples dealing with infertility are more likely to get pregnant if they adopt (50\%). On the other hand there were two items where over $30 \%$ of the respondents said were Definitely True: 4 : All boys have one $\mathrm{Y}$ chromosome and girls do not (41\%); and 7: A woman who is already pregnant can't get pregnant again (37\%).

On eleven items a quarter or more of the respondents said that they Don't Know. The top five were: 9: Female fetuses have faster heart rates than male fetuses (45\%); 45: Parent-child relationship disruptions can be repaired with holding therapy (39\%) and 23: Facilitated communication is effective for children with autism (35\%).

\subsection{Correlates}

Two scores were then computed for each individual: the total scores in each questionnaire in which they had marked Definitely False, meaning essentially a correct or well-informed score. For the first questionnaire the score was 18.89 $(\mathrm{SD}=8.12)$ and the second $17.79(\mathrm{SD}=8.12)$. The correlation between the two was $r=.79$ indicating considerable similarity in responses to the two questionnaires.

These scores were then correlated with various of the demographic and belief 
Table 1. Results from the first questionnaire.

\begin{tabular}{|c|c|c|c|c|c|c|}
\hline & Statement & DT & PT & $\mathrm{PF}$ & DF & $\mathrm{DK}$ \\
\hline 1 & Identical twins have a telepathic connection that originates in the womb. & 2.3 & 20.9 & 26.8 & 40.5 & 9.5 \\
\hline 2 & Couples dealing with infertility are more likely to get pregnant if they adopt. & 2.3 & 11.4 & 23.2 & 50.0 & 13.2 \\
\hline 3 & Parents can predict the sex of a foetus by examining the shape of the mother's body. & 0.9 & 9.5 & 19.5 & 64.1 & 5.9 \\
\hline 4 & All boys have one Y chromosome, and girls do not. & 40.5 & 24.1 & 8.2 & 10.5 & 16.8 \\
\hline 5 & $\begin{array}{l}\text { The "attachment" parenting approach with birth-bonding strengthens the mother-infant } \\
\text { relationship. }\end{array}$ & 16.8 & 38.6 & 10.0 & 6.4 & 28.2 \\
\hline 6 & Identical twins have identical genes. & 23.6 & 30.5 & 18.6 & 13.6 & 13.6 \\
\hline 7 & A woman who is already pregnant can't get pregnant again. & 36.8 & 22.3 & 15.5 & 14.5 & 10.9 \\
\hline 8 & The Chinese lunar calendar accurately predicts the sex of a baby. & 0.9 & 6.4 & 13.6 & 69.1 & 10.0 \\
\hline 9 & Female foetuses have faster heart rates than male foetuses. & 4.1 & 21.8 & 14.1 & 15.5 & 44.5 \\
\hline 10 & Epidurals create a high risk of harm during delivery of a baby. & 2.7 & 16.4 & 32.7 & 21.8 & 26.4 \\
\hline 11 & More babies are born during a full moon. & 3.6 & 11.8 & 21.8 & 31.4 & 31.4 \\
\hline 12 & Pre-chewing a baby's food has no known risks. & 1.4 & 13.2 & 29.5 & 25.5 & 30.5 \\
\hline 13 & Letting babies "cry it out" during bedtime is harmful to their development. & 6.4 & 17.3 & 37.3 & 20.9 & 18.2 \\
\hline 14 & Sugar intake causes children to be hyperactive. & 20.5 & 44.5 & 16.4 & 11.4 & 7.3 \\
\hline 15 & Using a baby walker will help a toddler walk sooner. & 7.3 & 35.9 & 20.9 & 13.2 & 22.7 \\
\hline 16 & Showing cognitively stimulating videos to babies boosts their intelligence. & 12.3 & 51.4 & 16.8 & 5.0 & 14.5 \\
\hline 17 & Using "baby talk" with an infant delays their ability to speak normally. & 10.0 & 27.3 & 32.3 & 16.4 & 14.1 \\
\hline 18 & A good response to stimulant medication is proof a child has ADHD. & 1.4 & 11.4 & 26.4 & 34.1 & 26.8 \\
\hline 19 & Requiring children to "clean their plates" promotes healthy eating habits. & 6.4 & 17.7 & 26.8 & 35.0 & 14.1 \\
\hline 20 & Dyslexia's defining feature is letter reversal. & 22.3 & 44.1 & 13.6 & 5.5 & 14.5 \\
\hline 21 & Most babies can learn to read with the right learning program. & 17.7 & 34.5 & 21.4 & 9.5 & 16.8 \\
\hline 22 & Educational kinesiology (Learning through movement) promotes learning in children. & 17.7 & 51.8 & 6.4 & 3.6 & 20.5 \\
\hline 23 & Facilitated communication is effective for children with autism. & 15.0 & 40.0 & 5.9 & 4.5 & 34.5 \\
\hline 24 & Dolphin-assisted therapy effectively treats children with special needs. & 8.6 & 37.7 & 12.3 & 8.6 & 32.7 \\
\hline 25 & Bed-wetting is a sing of serious emotional problems. & 2.7 & 15.5 & 40.9 & 23.6 & 17.3 \\
\hline 26 & Most antidepressants for children are approved by the FDA. & 10.0 & 28.2 & 17.78 & 19.5 & 24.5 \\
\hline 27 & Drawings contain specific signs useful in identifying subconscious problems. & 10.0 & 38.6 & 21.8 & 9.1 & 20.5 \\
\hline 28 & Most toddlers go through a "terrible twos" stage. & 16.4 & 47.7 & 18.6 & 5.0 & 12.3 \\
\hline 29 & Kids can be "scared straight" from delinquency. & 5.9 & 25.9 & 31.8 & 21.4 & 15.0 \\
\hline 30 & Parents can usually tell when their child is depressed. & 5.0 & 28.6 & 35.9 & 21.4 & 9.1 \\
\hline 31 & Young girls are more likely to have clinical depression than young boys. & 10.0 & 34.5 & 17.7 & 6.4 & 31.4 \\
\hline 32 & Helping children avoid their fears is the best way to decrease their anxiety. & 8.6 & 16.8 & 31.8 & 30.9 & 11.8 \\
\hline 33 & Adults can usually tell if a child is lying. & 6.8 & 40.5 & 30.9 & 15.5 & 6.4 \\
\hline 34 & Seeing other people be aggressive will decrease children's aggressive drive. & 3.6 & 9.1 & 29.5 & 46.4 & 11.4 \\
\hline 35 & School homicides are on the rise. & 15.5 & 34.5 & 16.4 & 10.5 & 23.2 \\
\hline
\end{tabular}




\section{Continued}

36 Drug Abuse Resistance Education (DARE) prevents drug use.

37 An "only child" is likely to be selfish, spoiled, and socially competent.

38 Divorce ruins most children's lives.

39 If you "spare the rod" you will "spoil the child".

40 Brief time-outs are too weak to help decrease real behavioral problems.

41 Daycare damages the attachment between children and parents.

42 Imaginary friends are a sign of social-emotional problems in children.

43 Birth order is a powerful predictor of a child's personality.

44 The most common reason for sibling fights is the rival for parental love.

45 Parent-child relationship disruptions can be repaired with holding therapy.

46 Fathers use more corporal punishment than mothers.

47 Rewards usually decrease the desirable behavior they are intended to increase.

48 Praise undermines children's ability to be successful.

49 Parents were not lenient when I was a child: they are becoming more lenient.

\begin{tabular}{lllll}
9.5 & 33.6 & 21.8 & 23.6 & 11.4 \\
$\mathbf{4 . 5}$ & 27.3 & 28.6 & 27.3 & 12.3 \\
$\mathbf{7 . 3}$ & 20.9 & 36.8 & 24.5 & 10.5 \\
$\mathbf{6 . 4}$ & 20.9 & 22.7 & $\mathbf{3 2 . 7}$ & 17.3 \\
$\mathbf{6 . 8}$ & 21.4 & 38.6 & 15.5 & 17.7 \\
$\mathbf{5 . 0}$ & 20.9 & 32.7 & 28.6 & 12.7 \\
$\mathbf{3 . 2}$ & 12.3 & 35.9 & $\mathbf{3 5 . 0}$ & 13.6 \\
$\mathbf{3 . 2}$ & 29.1 & 27.3 & $\mathbf{2 3 . 2}$ & 17.3 \\
$\mathbf{3 . 6}$ & 35.9 & 28.2 & $\mathbf{1 5 . 0}$ & 17.3 \\
$\mathbf{2 . 7}$ & 26.4 & 20.9 & $\mathbf{1 1 . 4}$ & 38.6 \\
$\mathbf{9 . 1}$ & 40.5 & 23.2 & $\mathbf{9 . 1}$ & 18.2 \\
$\mathbf{3 . 2}$ & 21.4 & 33.6 & $\mathbf{1 7 . 3}$ & 24.5 \\
$\mathbf{3 . 6}$ & 11.4 & 33.2 & $\mathbf{4 1 . 4}$ & 10.5 \\
$\mathbf{1 1 . 8}$ & 41.4 & 19.1 & $\mathbf{1 2 . 7}$ & 15.0 \\
\hline & & & &
\end{tabular}

a. DT $=$ Definitely True, $\mathrm{PT}=$ Probably True, $\mathrm{PF}=$ Probably False, $\mathrm{DF}=$ Definitely False, DK $=$ Don't Know.

Table 2. Results from the second questionnaire.

\begin{tabular}{|c|c|c|c|c|c|c|}
\hline & Statement & DT & $\mathrm{PT}$ & $\mathrm{PF}$ & DF & $\mathrm{DK}$ \\
\hline 1 & Thought resides in the heart: the heart is the home of mental functioning. & 2.3 & 11.4 & 12.3 & 68.2 & 5.9 \\
\hline 2 & The brain pumps animal spirits around the body. & 1.4 & 3.2 & 9.5 & 80.9 & 5.0 \\
\hline 3 & Brain cells join together forming a huge net of nerves. & 40.5 & 36.8 & 7.7 & 5.9 & 9.1 \\
\hline 4 & Mental function resides in the brain's hollows/spaces. & 6.8 & 34.5 & 20.0 & 21.8 & 16.8 \\
\hline 5 & Drilling a hole in the skull releases evil spirits. & 0.9 & 2.7 & 4.1 & 90.5 & 1.8 \\
\hline 6 & Personality can be accurately read in the bumps on the skull. & 2.7 & 6.8 & 18.2 & 65.9 & 6.4 \\
\hline 7 & Mental illness can be cured by disconnecting the frontal lobes-the front part of the brain. & 1.8 & 9.1 & 27.7 & 50.9 & 10.5 \\
\hline 8 & Brain injury has been shown to turn a quiet, hard-working man into an impulsive brute. & 24.1 & 43.2 & 13.6 & 9.1 & 10.0 \\
\hline 9 & The whole of the brain is in charge of the ability to produce language. & 10.5 & 34.1 & 19.5 & 26.4 & 9.5 \\
\hline 10 & Memory is distributed throughout the entire cortex. & 10.5 & 44.1 & 14.5 & 10.9 & 20.0 \\
\hline 11 & We only use $10 \%$ of our brains. & 13.6 & 28.2 & 22.3 & 30.9 & 5.0 \\
\hline 12 & Right-brained people are more creative than left-brained people. & 3.6 & 32.7 & 27.7 & 19.5 & 16.4 \\
\hline 13 & The female brain is more balanced than the male. & 2.7 & 17.3 & 31.4 & 22.7 & 25.9 \\
\hline 14 & Adults can't grow new brain cells. & 6.4 & 22.3 & 27.7 & 24.5 & 19.1 \\
\hline 15 & There is a "God Spot" (a place for processing faith) in the brain. & 6.4 & 21.4 & 22.7 & 34.2 & 15.5 \\
\hline 16 & Pregnant women seem to lose their minds (become forgetful, slow). & 6.8 & 20.0 & 25.9 & 35.5 & 11.8 \\
\hline 17 & We all need eight hours of continuous sleep a night. & 12.7 & 27.3 & 33.6 & 22.7 & 3.6 \\
\hline 18 & The brain is essentially a computer. & 29.1 & 44.1 & 13.6 & 7.7 & 5.5 \\
\hline 19 & The mind can exist outside the brain. & 4.5 & 17.7 & 22.7 & 37.7 & 17.3 \\
\hline 20 & Neuroscience is radically transforming human self-understanding. & 33.2 & 47.7 & 5.9 & 4.1 & 9.1 \\
\hline
\end{tabular}




\section{Continued}

\begin{tabular}{|c|c|c|c|c|c|c|}
\hline 21 & The brain is very well designed. & 56.8 & 29.1 & 6.8 & 5.0 & 2.3 \\
\hline 22 & The bigger the brain, the more intelligent the person. & 3.6 & 14.1 & 27.7 & 45.9 & 8.6 \\
\hline 23 & $\begin{array}{l}\text { You have a "grandmother cell" in the brain: a part all about processing information about } \\
\text { your grandmother. }\end{array}$ & 3.2 & 5.9 & 24.1 & 54.5 & 12.3 \\
\hline 24 & Glial cells are little more than brain "glue". & 3.2 & 20.5 & 10.5 & 12.3 & 53.6 \\
\hline 25 & Mirror neurons make us human. & 2.7 & 13.2 & 18.2 & 14.5 & 51.4 \\
\hline 26 & The brain is disembodied: separate from the body. & 2.3 & 8.6 & 21.4 & 58.2 & 9.5 \\
\hline 27 & Brain scans can literally "read your mind". & 1.8 & 16.4 & 20.9 & 54.1 & 6.8 \\
\hline 28 & Neuro-feedback can provide pleasure and enlightenment. & 10.0 & 45.5 & 12.7 & 5.9 & 25.9 \\
\hline 29 & Brain training will make you smarter. & 18.2 & 51.8 & 18.2 & 5.0 & 6.8 \\
\hline 30 & Brain food will make you smarter. & 6.8 & 29.1 & 37.3 & 18.2 & 8.6 \\
\hline 31 & Spending too much time on Google will make you stupid and go mad. & 3.6 & 5.9 & 20.0 & 67.3 & 3.2 \\
\hline 32 & The brain receives information from five separate senses. & 42.7 & 38.2 & 7.7 & 6.4 & 5.0 \\
\hline 33 & The brain perceives the world as it is. & 9.1 & 25.9 & 32.7 & 23.2 & 9.1 \\
\hline 34 & The brain's representation of the body is accurate and stable. & 5.9 & 33.6 & 34.1 & 12.3 & 14.1 \\
\hline 35 & $\begin{array}{l}\text { After head injury, people can forget who they are and not recognize others, but be normal } \\
\text { in every other way. }\end{array}$ & 50.9 & 37.7 & 5.9 & 2.7 & 2.7 \\
\hline 36 & People suffering from amnesia typically cannot recall their own name or identity. & 31.8 & 41.8 & 12.7 & 4.1 & 9.5 \\
\hline 37 & People in comas usually recover. & 5.0 & 21.8 & 40.0 & 14.5 & 18.6 \\
\hline 38 & Epilepsy is caused by abnormalities in blood flow in the brain. & 8.2 & 37.3 & 13.6 & 7.3 & 33.6 \\
\hline 39 & A concussion is not a form of brain injury. & 3.6 & 3.2 & 15.5 & 71.4 & 6.4 \\
\hline 40 & Strokes only affect old people. & 3.2 & 3.6 & 9.5 & 81.4 & 2.3 \\
\hline 41 & The effects of stroke are limited to physical disability. & 2.3 & 7.3 & 12.7 & 71.4 & 6.4 \\
\hline 42 & Strokes are unpreventable. & 1.8 & 12.7 & 40.0 & 35.5 & 10.0 \\
\hline 43 & Traumatic memories are usually repressed memories. & 6.4 & 37.3 & 25.9 & 13.6 & 16.8 \\
\hline 44 & Memory works like a video recorder. & 10.5 & 32.7 & 20.0 & 25.0 & 11.8 \\
\hline 45 & There is such a thing as 'photographic' memory. & 29.1 & 37.3 & 16.8 & 9.1 & 7.7 \\
\hline 46 & 'Flashbulb' memories are highly accurate. & 4.1 & 18.6 & 27.3 & 8.2 & 41.8 \\
\hline 47 & Everyone with autism has a rare intellectual gift. & 2.3 & 17.3 & 25.5 & 34.5 & 20.5 \\
\hline 48 & Autism is caused by the MMR vaccine. & 0.9 & 5.0 & 16.4 & 59.5 & 18.2 \\
\hline 49 & There is an autism epidemic. & 5.5 & 17.7 & 26.8 & 33.6 & 16.4 \\
\hline 50 & People with autism are introverted and uncaring. & 1.4 & 9.5 & 28.6 & 46.4 & 14.1 \\
\hline 51 & Autism is only about disability. & 1.4 & 4.5 & 28.6 & 52.7 & 12.7 \\
\hline 52 & There is a cure for autism. & 1.4 & 10.9 & 25.5 & 48.2 & 14.1 \\
\hline 53 & Alzheimer's is the same as dementia. & 3.6 & 20.0 & 25.9 & 39.5 & 10.9 \\
\hline 54 & Dementia only affects older people. & 2.7 & 14.1 & 31.4 & 44.5 & 7.3 \\
\hline 55 & People with dementia are like "zombies". & 1.8 & 10.5 & 20.5 & 58.2 & 9.1 \\
\hline 56 & Mental illnesses are caused by chemical imbalances in the brain. & 24.1 & 54.1 & 7.7 & 3.6 & 10.5 \\
\hline
\end{tabular}

a. DT = Definitely True, PT = Probably True, PF = Probably False, DF = Definitely False, DK = Don't Know. 
variables. There was no relationship between either total score and age, gender, education, whether they had children and whether or not they had taken a course in psychology. Indeed, scores of those who had and had not some education in psychology were almost identical. Three variables were significant for both total scores: they indicated the more religious people were the higher their score: test $1, \mathrm{r}=0.24$, test $2, \mathrm{r}=0.19$; more politically conservative had a higher score (test $1, r=0.23$; test $2, r=0.18$ ) and the more they believed they had Common Sense the higher their score (test $1, r=0.22$; test $2, r=0.26$ ).

A number of regressions were then computed, with both test total scores as the criterion variable. In the first set age, gender, having taken a psychology course and self-assessed common sense was entered as predictor variables. The regression was significant for both tests: test 1 : $(\mathrm{F}(4,219)=3.40, p<0.01$; Adj $\left.\mathrm{R}^{2}=0.04\right)$ and test $2:\left(\mathrm{F}(4,219)=4.57, p<0.001\right.$; Adj $\left.\mathrm{R}^{2}=0.06\right)$. In both cases only self-assessed common sense was significant Test 1 Beta $=.22, \mathrm{t}=3.37, \mathrm{p}$ $<.001$; Test 2 Beta 0.26, $\mathrm{t}=4.05, p<0.001)$. Those with higher self-assessed common sense were indeed more able to detect myths. In this sense participants were indeed self-aware.

The two scores were then combined to produce a total score which served as a criterion variable. There were eight predictor variables: age, gender, education, having taken a psychology course, self-assessed common sense, having children, religious beliefs and political beliefs. This was significant $(\mathrm{F}(8,211)=4.50, p<$ 0.001 , Adj $\left.\mathrm{R}^{2}=0.11\right)$. Two variables were significant predictors: Common Sense $($ Beta $=0.21, \mathrm{t}=3.13, p<0.01)$ and religious beliefs (Beta $=0.18, \mathrm{t}=2.47, p<$ $0.01)$. Those with higher self-rated common sense and greater religious beliefs were better able to detect these myths.

\section{Discussion}

The current results replicated findings of earlier studies on misconception prevalence (Arntzen, et al., 2010; Furnham \& Hughes, 2014) showing that a large number of myths were widely believed. Overall, it seemed that participants were better at identifying Brain Myths compared to Child Developmental myths, though this may be for methodological reasons. Many researchers have categorized myths into various topics like learning and neuromyths (De Bruyckere et al., 2015) though the research tends to show that participants are not particularly better informed and better "myth-detectors" in some areas of study rather than others.

It should be pointed out that when authors list myths of various kinds such as in the book series Great Myths in Psychology commissioned by Wiley they do not indicate the extent to which they believe (or have any data) on the extent to which people would endorse the myths. Nor do they write the statements in such a way as they may easily be understood without reading the subsequent text. In this sense the myths are not all equally clear and easily understood which is the finding of this and other studies. 
One interesting finding that was similar to the study of Furnham and Hughes (2014) was the fact that around 15\% - 20\% answered Don' Know to the questions. This number varied question by question but on average less than a fifth of respondents were prepared to admit that they did not know. We calculated the total scores for individuals on Don't Know but this was not systematically related to any of the demographic variables. It could be that people were too embarrassed to admit they did not know when indeed the evidence shows quite clearly that they did not.

This, like other studies in the area, failed to find any strong, clear or logical demographic correlates of myth accepting or rejecting. Age, gender and education were not related to total correct scores, nor education in psychology. Some, but not all, previous studies did establish a small but significant relationship between education in psychology and myth recognition (Furnham \& Hughes, 2014). This study found no such relationship, however this may be because of the lack of detail about that education. The question was simply "Did you ever take a course in psychology/psychiatry: Yes ... No ...”. As a result, we did not have details about the nature, depth and duration of the course, nor when and where it was undertaken. However, previous studies that collected much more detailed data about general and psychological education also showed, surprisingly, very few significant links.

Both the correlational and regression results did indicate one individual difference marker of myth detection. Those who rated themselves higher on "having common sense" were better detectors of myths. Descartes observed that "common sense is the most widely distributed human characteristic because everybody believes they have a great deal of it" which was reflected in the strong skew on this dimension. Thus, whereas most people agreed to this statement it nevertheless proved a significant correlate of myth detection. There was also some indication that religious and political beliefs were linked to myth detection though the correlations were low. The results were rather surprising showing that more religious and right-wing people tended to be better at myth detection. Some studies have suggested that together political and religious beliefs assess a participants' ideology. This interesting finding requires both replication and explanation.

The current study has shown that psychological myths and misconceptions (about the brain and child development) are abundant and persistent as well as potentially harmful and socially divisive. It is possible that myth-debunking campaigns designed around reputational methods akin to those used by Kowalski and Taylor (2009), Lilienfeld et al., (2010), and LaCaille (2015) have the potential to reduce levels of misconception. The current study can be used to identify myths and misconceptions in need of refutation.

Like all others this study had limitations. It used a modestly sized convenience rather than a population sample. Further, the test was relative long and it may have meant that some respondents got into a particular response mindset 
(Furnham et al., 2015). However, a preliminary "data clean-up" suggested that very few (around 15\%) of participants were eliminated for their erratic, incomplete or patterned response set. Also, some of the wording of the statements required some clarification. Further, all the correct answers were false, as in all other studies in this area which may have induced certain response biases. Indeed, this paper may be considered as a pilot for a second study where a reduced number of myths were chosen based on the result of this study perhaps concentrating on those where most participants believed them to be true.

\section{Conclusion}

Studies such as this provide useful historical data on psychological myth prevalent in society. They nearly always provide the "shocking truth" about the widespread acceptance of myths which nearly always concern experts and educationists who call for attempt to dispel or debunk those myths. The question of how to combat these myths and ensure that people are better informed about various areas of psychology remains largely unanswered.

\section{References}

Arntzen, E., Lokke, J., Lokke, G., \& Eilertsen, D.-E. (2010). On Misconceptions about Behavior Analysis among University Students and Teachers. Psychological Record, 60, 325-336. https://doi.org/10.1007/BF03395710

Bensley, D. A., Lilienfeld, S. O., \& Powell, L. A. (2014). A New Measure of Psychological Misconceptions: Relations with Academic Background, Critical Thinking, and Acceptance of Paranormal and Pseudoscientific Claims. Learning and Individual Differences, 36, 9-18. https://doi.org/10.1016/j.lindif.2014.07.009

Brown, L. T. (1983). Some More Misconceptions about Psychology among Introductory Psychology Students. Teaching of Psychology, 10, 207-210.

https://doi.org/10.1207/s15328023top1004_4

Buhrmester, M., Kwang, T., \& Gosling, S. D. (2011). Amazon's Mechanical Turk a New Source of Inexpensive, Yet High-Quality, Data? Perspectives on Psychological Science, 6, 3-5. https://doi.org/10.1177/1745691610393980

De Bruyckere, P., Kirschner, P., \& Hulshof, C. (2015). Urban Myths about Learning and Education. London: Elsevier.

Furnham, A. (1992). Prospective Psychology Students' Knowledge of Psychology. Psychological Reports, 70, 375-382. https://doi.org/10.2466/pr0.1992.70.2.375

Furnham, A. (1993). A Comparison between Psychology and Non-Psychology Students' Misperceptions of the Subject. Journal of Social Behavior and Personality, 8, 311-322.

Furnham, A., \& Hughes, D. (2014). Myths and Misconceptions in Popular Psychology: Comparing Psychology Students and the General Public. Teaching of Psychology, 41, 256-261. https://doi.org/10.1177/0098628314537984

Furnham, A., Hyde, G., \& Trickey, G. (2015). Personality and Value Correlates of Careless and Erratic Questionnaire Responses. Personality and Individual Differences, 54, 716-720. https://doi.org/10.1016/j.paid.2012.11.030

Gardner, R. M., \& Brown, D. L. (2013). A Test of Contemporary Misconceptions in Psychology. Learning and Individual Differences, 24, 211-215.

https://doi.org/10.1016/j.lindif.2012.12.008 
Gardner, R. M., \& Dalsing, S. (1986). Misconceptions about Psychology among College Students. Teaching of Psychology, 13, 32-34.

https://doi.org/10.1207/s15328023top1301_9

Griggs, R. A., \& Ransdell, S. E. (1987). Misconceptions Tests or Misconceived Tests? Teaching of Psychology, 14, 210-214. https://doi.org/10.1207/s15328023top1404_4

Hupp, S., \& Jewell, J. (2015). Great Myths of Child Development. New York: WileyBlackwell.

Jarrett, C. (2014). Great Myths of the Brain. New York: Wiley-Blackwell.

Kowalski, P., \& Taylor, A. (2009). The Effect of Refuting Misconceptions in the Introductory Psychology Class. Teaching of Psychology, 36, 153-159. https://doi.org/10.1080/00986280902959986

LaCaille, R. (2015). Two Birds with One Myth-Debunking Campaign. Teaching of Psychology, 42, 323-329. https://doi.org/10.1177/0098628315603066

Lamal, P. A. (1979). College Students' Common Beliefs about Psychology. Teaching of Psychology, 6, 155-158. https://doi.org/10.1207/s15328023top0603_8

Lilienfeld, S., Lynn, S., Ruscio, J., \& Beyerstein, B. (2010). 50 Great: Popular Myths of Popular Psychology. Oxford: Wiley-Blackwell.

McKeachie, W. (1960). Changes in Scores on the Northwestern Misconceptions Test in Six Elementary Psychology Courses. Journal of Educational Psychology, 51, 240-244. https://doi.org/10.1037/h0048569

Nixon, H. (1925). Popular Answers to Some Psychological Questions. American Journal of Psychology, 27, 91-98. https://doi.org/10.2307/1414166

Standing, L., \& Huber, H. (2003). Do Psychology Courses Reduce Belief in Psychological Myths? Social Behavior and Personality, 31, 585-592.

https://doi.org/10.2224/sbp.2003.31.6.585

Swami, V., Thorn, L., Husbands, D., Tran, U. S., Nader, I. W., von Nordheim, L., Pietschnig, J., Stieger, S., \& Voracek, M. (2015). Are the Scope and Nature of Psychology Properly Understood? An Examination of Belief in Myths of Popular Psychology among University Students. In A. Columbus (Ed.), Advances in Psychology Research (Vol. 101, pp. 9-32). Hauppage, NY: Nova Science Publishers.

Taylor, A., \& Kowalski, P. (2004). Naive Psychological Science: The Prevalence, Strength and Sources of Misconceptions. Psychological Record, 54, 15-25. https://doi.org/10.1007/BF03395459

Tupper, V., \& Williams, R. (1986). Unsubstantiated Beliefs among Beginning Psychology Students: 1925, 1952, 1983. Psychological Reports, 58, 383-388. https://doi.org/10.2466/pr0.1986.58.2.383

Vaughan, E. D. (1977). Misconceptions about Psychology among Introductory Psychology Students. Teaching of Psychology, 4, 138-141. https://doi.org/10.1207/s15328023top0403_9 